\title{
PENGARUH KOMBINASI EKSTRAK JERUK BRASTAGI DAN WORTEL PER ORAL SEBELUM AKTIVITAS FISIK TERHADAP KADAR MALONDIALDEHID PLASMA MENCIT DALAM BERBAGAI DURASI AKTIVITAS FISIK
}

\author{
Felix Samuel $^{1,2}$, Hanna Goenawan ${ }^{3}$, Aziiz M. Rosdianto ${ }^{3}$, Juliati $^{3}$ \\ ${ }^{1}$ Program Studi Ilmu Kedokteran Dasar, Fakultas Kedokteran, Universitas Padjadjaran \\ ${ }^{2}$ Fakultas Pendidikan Olahraga Dan Kesehatan, Universitas Pendidikan Indonesia \\ ${ }^{3}$ Departemen Anatomi, Fisiologi, dan Biologi Sel, Fakultas Kedokteran, Universitas Padjadjaran
}

\section{Abstract}

Under specific circumstances such as during aerobic predominant exercise, production of free radical increases and creates free radicals-endogen antioxidants imbalance. It causes oxidative stress. The level of oxidative stress can be recognized by measuring the level of plasma malondialdehyde (MDA). But the effect of physical activity and effect of exogenous antioxidants supplementation are still not clearly known in literature. Based on the background above, as preliminary study, the writter conduct a study to investigate the plasma MDA level on mice which is given and not given combination of Brastagi's oranges and carrots juice before physical activity using mice's treadmill for 10,20, and 30 minutes. The research methode used in this study is an experimental laboratory study. As objects of this study are 24 mice(mus musculus), white colored, male, weighting 25-30 grams, which is randomly chosen. The objects are divided into 2 groups, Group A : 12 mice (given combination of Brastagi's oranges and carrots juice before physical activity using mice's treadmill) and group $B: 12$ mice (not given combination of Brastagi's oranges and carrots juice before physical activity using mice's treadmill). Group A are divided into 3 subgroups : A1 (doing treadmill for 10 minutes), A2 (doing treadmill for 20 minutes), and A3 (doing treadmill for 30 minutes). The same procedure are employed for the group B. Plasma MDA level measured after doing physical activity using mice treadmill. The homogeneity of the result then was tested using Levene's test and the normality of the result was tested using Kolmogorov-smirnov test ( $p>0.05)$. Further, the data was analyzed using independent t-test $(p \leq 0.05)$, one-way ANOVA $(p \leq 0.05)$ then Duncan's test were used. The analyzed data indicated combination of Brastagi's oranges and carrots juice supplementation given to mice before physical activity, for 10,20, and 30 minutes caused lower plasma MDA level than mice not given combination of Brastagi's oranges and carrots juice before physical activity. The differences are $38,44 \%(0,5277$ vs 0,8571$)$ (A1-B1); $37,96 \%(0,5866$ vs 0,9455$)(\mathrm{A} 2-\mathrm{B} 2)$; dan77,79\% (0,8438 vs 1,6161$)$ (A3-B3). The conclusion of the study suggested that combination of Brastagi's oranges and carrots juice supplementation given to mice before physical activity for 10,20, and 30 minutes caused lower plasma MDA level than mice not given combination of Brastagi's oranges and carrots juice before physical activity.

Keywords : Malondialdehyde (MDA), free radicals, combination of Brastagi's orange and carrots juice, antioxidants

Korespondensi: Felix Samuel, E-mail: samuelfelix039@gmail.com, Departemen Anatomi, Fisiologi, dan Biologi Sel, Fakultas Kedokteran Universitas Padjadjaran. Jalan Raya Jatinangor Km 21, Sumedang, Jawa Barat, Indonesia. 


\section{PENDAHULUAN}

Radikal bebas merupakan suatu zat yang dihasilkan dari proses metabolisme di dalam sel. Radikal bebas berperan dalam menyebabkan kerusakan sel dan diyakini memiliki peranan penting dalam proses penuaan dan proses progresi dari berbagi penyakit (Percival,1998). Metabolisme di dalam sel akan menghasilkan radikal bebas yang jumlahnya sangat tergantung dari berbagai faktor. Dalam keadaan normal, radikal bebas diproduksi dalam sel dan kadarnya akan meningkat pada aktivitas fisik yang berat dalam suasana metabolisme aerobik, proses oksidatif dari sel darah putih, dan hasil dari metabolisme xenobiotic (Percival,1998).

Kemampuan tubuh menggunakan oksigen dalam proses metabolisme menyebabkan oksigen yang terlibat dalam proses metabolisme tersebut bereaksi dengan substrat tertentu yang menghasilkan senyawa tidak stabil yang dikenal dengan nama radikal bebas atau oksidan. Pada keadaan tertentu jumlah oksidan yang terbentuk akan mengalami peningkatan yang cukup besar dan keadaan ini menyebabkan ketidak-seimbangan antara jumlah oksidan yang terbentuk di dalam sel dengan kadar antioksidan yang dihasilkan dari dalam tubuh. Jumlah oksidan dan antioksidan yang tidak seimbang akan menimbulkan stres oksidatif (Papas, 1999). Kondisi ini terjadi karena ada peningkatan konsumsi oksigen ke dalam sel otot untuk memenuhi kebutuhan proses metabolisme sel otot yang pada akhirnya meningkatnya produksi superoksida. Superoksida akan mengakibatkan terganggunya komposisi asam lemak membran sel dan terjadinya kebocoran enzim dan faktor kemotaksis sehingga sel menjadi rusak secara fungsional dan struktural (Papas, 1999).

Aktivitas fisik menyebabkan peningkatan produksi dari radikal bebas dan Reactive oxygen Species (ROS)yang diketahui dapat menyebabkan stres oksidatif. Selama berolahraga proses suplai oksigen ke otot akan menyebabkan oksidasi dari Polyunsaturated Fatty Acids(PUFA) di mitokondria. Sehingga akan menghasilkan ROS yang bersifat sitotoksik yang akan menyebabkan kelelahan otot. Hal ini terjadi utamanya pada atlet yang melakukan latihan fisik yang berat, sehingga menjadi rentan mengalami cedera (Metin, dkk., 2003). Aktivitas fisik yang berlangsung dalam jangka waktu yang lama maka akan menimbulkan produksi radikal bebas yang bertambah pula. Hal ini menyebabkan timbunan radikal bebas akan semakin meningkat seiring bertambahnya waktu aktivitas fisik sehingga kebutuhan asupan antioksidan eksogen menjadi penting ( $\mathrm{Li}, 2000)$.
Untuk melindungi sel dan organ dari efek radikal bebas, tubuh manusia memiliki sistem pertahanan yang kompleks yang terdiri dari antioksidan endogen dan eksogen yang bekerja secara sinergis dalam menangkal efek negatif dari radikal bebas. Adapun antioksidan endogen meliputi : enzim-enzim antioksidan (Superoxide dismutase, glutathione peroxidase, dan glutathione reductase), dan metal bindings proteins (ferritin, albumin, dan ceruloplasmin). Apabila kadar radikal bebas intraseluler relatif terlalu tinggi maka kemampuan antioksidan endogen untuk mengeliminasi radikal bebas yang terbentuk kurang memadai. Oleh karena itu diperlukan tambahan antioksidan eksogen dari berbagai fitonutrien yang berasal dari tumbuhtumbuhan, dan yang paling banyak digunakan dan diteliti adalah antioksidan yang diperoleh dari makanan antara lain vitamin C (Ascorbic acid) yang banyak terdapat pada buah jeruk Brastagi dan $\beta$ karotenyang banyak terdapat pada wortel. Berdasarkan uraian di atas maka peran antioksidan eksogen dalam memberikan perlindungan pertama terhadap radikal bebas merupakan sesuatu yang penting (Percival,1998). Informasi tentang pengaruh dari vitamin $\mathrm{C}$ yang banyak terdapat pada jeruk Brastagi dan $\beta$ karoten yang banyak terdapat pada wortel untuk menurunkan radikal bebas sampai saat ini relatif masih sangat terbatas.

Buah-buahan dan sayur-sayuran seperti jaruk Brastagi dan wortel. merupakan sumber daya alam lokal yang amat berlimpah di bumi Indonesia ini. Tanah pertanian yang subur dan luas menghasilkan hasil pertanian dan perkebunan yang berkualitas tinggi. Salah satu hasilnya adalah buah jeruk Brastagi. Jeruk Brastagi merupakan buah yang berasal dari daerah Sumatera Utera dan namanya sudah dikenal secara luas di seluruh Indonesia. Jeruk Brastagi dikenal karena rasanya yang manis dan harganya yang ekonomis sehingga jeruk ini relatif banyak dikonsumsi oleh masyarakat. Demikian pula halnya dengan wortel, wortel termasuk jenis tumbuhan sayur yang banyak tumbuh di Jawa Barat. Perkebunan wortel milik rakyat tersebar di manamana. Wortel amat dikenal di masyarakat dan bahkan dikonsumsi secara rutin karena rasanya yang lezat, mudah diolah dan harganya yang terjangkau. Namun selain sebagai sumber bahan pangan, peran Jeruk Brastagi dan wortel sebagai sumber nutrients derived antioxidants belum banyak diketahui. Jeruk Brastagi sebagai sumber vitamin $\mathrm{C}$ dan wortel sebagai sumber $\beta$ karoten merupakan sumber antioksidan yang alami, murah dan bermanfaat dalam mengurangi efek negatif radikal bebas. Namun sampai saat ini masyarakat pada umumnya belum mengetahui kapan waktu pemberian dan takaran pemberian yang tepat dari vitamin $C$ dan $\beta$ 
karoten yang banyak terkandung dalam jeruk Brastagi dan wortel agar memberi manfaat yang maksimal dalam menetralkan oksidan yang terbentuk secara berlebihan di dalam tubuh, terutama pada saat melakukan aktivitas fisik dan dikaitkan dengan lamanya melakukan aktivitas fisik tersebut.

Sebagaimana tercantum diatas, aktivitas aerobik intensitas tinggi akan menghasilkan radikal bebas. Untuk mengukur radikal bebas yang terbentuk saat melakukan aktivitas aerobik intensitas tinggi sangat sulit (Jenkin,2000). Hal ini dikarenakan sifat senyawa tersebut yang sangat reaktif dan cepat berubah menjadi senyawa lain (Kretschmar dan Muller,1993). Oleh karena itu dilakukan cara lain untuk mengukur kadar radikal bebas yang terbentuk tersebut, yaitu dengan mendeteksi produk yang dihasilkan oleh reaksi radikal bebas, salah satunya adalah senyawa malondialdehid (MDA) (Niellsen,dkk.,1997). Selama berolahraga produksi radikal bebas meningkat, sebagai parameter dari tingkat stres oksidatif, maka kadar MDA pada individu yang berolahraga pun meningkat pula (Metin,dkk., 2003). Seiring bertambahnya waktu, aktivitas fisik predominan aerobik akan menimbulkan produksi radikal bebas yang bertambah pula sehingga kadar MDA plasma pun turut serta meningkat (Li, 2000)

Sampai dengan saat ini belum ada informasi tentang pengaruh pemberian kombinasi ekstrak jeruk Brastagi dan wortel terhadap penurunan radikal bebas pada manusia. Oleh karena itu untuk tahap penelitian awal, dilakukan penelitian pada mencit yang diukur kadar MDA nya setelah melakukan aktivitas fisik selama 10, 20, 30 menit yang pada akhirnya kemungkinan dapat diaplikasikan pada manusia.

Mencit (Mus muculus) memiliki mekanisme pertahanan khusus yang menyerupai pada manusia, yang berfungsi mencegah kerusakan tubuh terhadap timbulnya oksidan yang berlebihan (Whitney,2005). Untuk mencegah dampak negatif dari stres oksidatif radikal bebas pada mencit dibutuhkan antioksidan tambahan yang berasal dari luar (eksogen) untuk membantu kerja antioksidan endogen. Antioksidan eksogen yang dapat dikonsumsi sangat beragam, antara lain vitamin $C$, vitamin $E$, retinol (vitamin A), $\beta$ karoten, flavonoid, dan lain sebagainya (Frei, 2003). Berbagai macam antioksidan tersebut terkandung dalam buah dan sayur diantaranya : Vitamin $\mathrm{C}$ banyak terkandung pada jeruk Brastagi (Citrus sinensis) dan $\beta$ karoten yang banyak terkandung pada wortel (Daucus carota).

Berdasarkan uraian diatas maka dilakukan penelitian untuk mengetahui perbedaan pengaruh lama aktivitas fisik terhadap kadar malondialdehid pada mencit yang sebelumnya diberi dengan yang tidak diberi kombinasi ekstrak jeruk Brastagi dan wortel.

\section{METODE}

Objek penelitian berupa mencit (mus musculus) putih jantan dari galur Swibsibter umur 8 minggu dengan berat badan 25-30 gram yang dipilih secara acak, berjumlah 24 ekor mencit yang dibagi menjadi 6 kelompok dan masingmasing kelompok terdiri dari 4 ekor mencit.

Hewan penelitian diberi makan campuran pelet dan gabah dan diberi minum secukupnya selama penelitian.

Penentuan jumlah sampel tiap kelompok didasarkan pada formulasi Federrer. Banyaknya perlakuan adalah 6, sehingga jumlah sampel tiap kelompok adalah sebagai berikut:

$$
\begin{aligned}
& (\mathrm{r}-1)(\mathrm{t}-1) \geq 15 \\
& (\mathrm{r}-1)(6-1) \geq 15 \\
& (\mathrm{r}-1) 5 \geq 15 \\
& (\mathrm{r}-1) \geq 15 / 5 \\
& \mathrm{r} \geq 4
\end{aligned}
$$

Kriteria inklusi pada penelitian ini adalah:

1. Mencit (Mus musculus) putih jantan galur Swibsibter

2. Berumur 8 minggu

3. Berat badan rata-rata 25-30 gram

4. Didapatkan dari tempat pembiakan yang sama, pakan yang sama.

Tipe penelitian adalah studi eksperimental laboratorium dalam bidang Ilmu Faal dan Kedokteran Olahraga yang dilanjutkan dengan pemeriksaan darah. Eksperimen dilakukan di laboratorium Unit Penelitian Kesehatan RSHS Bandung..

Variabel penelitian ini terdiri variabel perlakuan (independent) dan variabel respon (dependent).

1. Variabel perlakuan adalah aktivitas fisik, kombinasi ekstrak jeruk Brastagi dan wortel

2. Variabel respon penelitian ini adalah kadar MDA plasma mencit

Untuk mengetahui perbedaan pengaruh lama aktivitas fisik terhadap kadar malondialdehid pada mencit yang sebelumnya diberi dengan yang tidak diberi kombinasi ekstrak jeruk Brastagi dan wortel dilakukan pengambilan sampel mencit dari populasi secara acak sebanyak 24 ekor yang kemudian dibagi menjadi dua kelompok, yaitu kelompok A sebanyak 12 ekor yang diberi kombinasi ekstrak jeruk Brastagi dan wortel sebelum melakukan aktivitas fisik pada treadmill tikus dengan kecepatan 1,25 m/s (Chapell, 2004), dan kelompok B sebanyak 12 ekor yang tidak diberi kombinasi ekstrak jeruk Brastagi dan wortel sebelum aktivitas fisik pada treadmill tikus dengan kecepatan $1,25 \mathrm{~m} / \mathrm{s}$ (Chapell, 2004). Selanjutnya kelompok A dan B masing-masing 
dibagi menjadi 3 kelompok, yaitu kelompok 1 yang diberi latihan treadmill selama 10 menit sebanyak 4 ekor, kelompok 2 yang diberi latihan treadmill selama 20 menit sebanyak 4 ekor, kelompok 3 yang diberi latihan treadmill selama 30 menit sebanyak 4 ekor. Pada kelompok B dilakukan penelitian sebagaimana prosedur yang sama seperti pada kelompok A.

Setelah kelompok A1, A2, A3, B1, B2, B3 diberi aktivitas fisik aerobik intensitas tinggi, maka mencit dimatikan dan diambil darahnya dari jantung atau hati. Data dari hasil pengukuran dikumpulkan untuk dianalisis secara statistik untuk mengetahui sebesar besar pengaruh perbedaan lama aktivitas fisik terhadap kadar MDA pada mencit yang sebelumnya diberi dengan yang tidak diberi ekstrak jeruk Brastagi dan wortel.

Pemeriksaan MDA dilakukan dengan prosedur sebagai berikut: darah mencit diambil sebanyak 1 $\mathrm{ml}$, sampel darah ini kemudian dimasukkan ke dalam tabung reaksi yang telah diberi antikoagulan. Tabung reaksi dibolak-balik sehingga tercampur sempurna, kemudian didiamkan selama 30 menit dalam pendingin.

Kemudian sampel darah disentrifuge pada 400 rpm selama 10 menit. Setelah darah selesai disentrifuge dengan hati-hati plasma diambil dengan pipet mikro. Tabung reaksi diisi dengan 700 mikroliter plasma darah yang dianalisis dan dicampur dengan 200 mikroliter larutan SDS, 50 mikroliter larutan BHT, 50 mikroliter larutan EDTA, 1500 mikroliter larutan asam asetat teknis dan 1500 liter mikrolarutan TBA. Campuran kemudian dipanaskan dalam penangas air pada suhu $100 \mathrm{C}$ selama 60 menit. Kemudian campuran diangkat dan didinginkan dalam bak es. Setelah itu campuran disentrifugasi dengan kecepatan $2335 \mathrm{rpm}$ selama 10 menit. Absorbansi supernatan diukur dengan speoktrofoto-meter visibel pada panjang gelombang $532 \mathrm{~nm}$. Untuk setiap sampel darah dilakukan uji minimal 2 kali. Hasil pembacaan tersebut kemudian dicari nilai rata-ratanya, nilai rata-rata tersebut kemudian dikonversikan ke dalam mikro mol/liter (Ohkawa, Ohisi, Yagi 1997). Kadar MDA ditentukan dengan rumus sebagai berikut:

Kadar MDA sampel $=$ (Absorbansi sampel: absorbansi standar ) X kadar MDA (nmol/mL) standar

\section{Analisis Data}

Analisis data penelitian diproses dengan program SPSS 15.0 for windows dengan langkahlangkahnya sebagai berikut:

Data yang diperoleh melalui hasil pengukuran kemudian dilakukan uji

1. Homogenitas data dengan uji Levene $(p>0,05)$

2. Normalitas dengan uji Kolmogorov-Smirnov $(\mathrm{p}>0,05)$

3. Untuk mengetahui perbedaan kadar MDA plasma mencit sebelum aktivitas fisik , sesudah pemberian ekstrak jeruk Brastagi dan wortel, maka jika data berdistribusi normal dan memiliki varian homogen maka untuk menguji perbedaan antara kedua kelompok, analisis dilanjutkan dengan uji-t tidak berpasangan $(\mathrm{p} \leq 0,05)$, uji one-way ANOVA $(\mathrm{p} \leq 0.05)$ dan selanjutnya dilanjutkan dengan uji Duncan. Sementara itu jika data tidak berdistribusi normal dan atau data tidak homogen, maka analisis yang digunakan adalah uji jenjang bertanda Wilcoxon (nonparametrik).

\section{HASIL dan DISKUSI}

Rata - rata dan standar deviasi karakteristik fisik fisiologis objek penelitian berupa berat badan (gram) dan kadar malondialdehid dalam berbagai pengukuran $(\mathrm{nmol} / \mathrm{mL})$ terdapat pada tabel 1. Dari rata-rata dan simpangan baku kadar MDA plasma pada berbagai pengukuran yang terdapat pada tabel 1 dilakukan uji normalitas Kolmogorov-Smirnov $(\mathrm{p}>0,05)$ dan uji homogenitas varians levene test $(\mathrm{p}>0,05)$, hasilnya menunjukkan data berdistribusi normal dan varians yang relatif homogen seperti tertera pada tabel 2 dan tabel 3 berikut ini.

Pengujian selanjutnya yaitu perbedaan pengaruh aktivitas fisik selama 10, 20 dan 30 menit terhadap kadar malondialdehid pada mencit yang sebelumnya diberi dengan yang tidak diberi kombinasi ekstrak jeruk Brastagi dan wortel dengan menggunakan statistik uji $\mathrm{t}$ independen dapat dilakukan. Serta untuk mengetahui efektivitas mana yang lebih berpengaruh dari aktivitas fisik selama 10, 20 dan 30 menit dan kontrol terhadap kadar malondialdehid pada mencit pada kelompok yang sebelumnya diberi dan yang tidak diberi kombinasi ekstrak jeruk Brastagi dan wortel digunakan analisis anava. Hasil pengujian tersebut dapat dilihat pada tabel hasil perhitungan berikut. 
Tabel 1 Karakteristik Fisik Fisiologis Objek Penelitian

\begin{tabular}{lrrrr}
\hline \multicolumn{1}{c}{ Berat Badan dan Kadar MDA } & X & \pm & & S \\
\hline Berat Badan (gram) & 27,58 & \pm & 1,32 \\
A1 : Aktivitas fisik 10 menit dengan ekstrak $(\mathrm{nmol} / \mathrm{ml})$ & 0,5277 & \pm & 0,0789 \\
A2 : Aktivitas fisik 20 menit dengan ekstrak $(\mathrm{nmol} / \mathrm{ml})$ & 0,5866 & \pm & 0,0589 \\
A3 : Aktivitas fisik 30 menit dengan ekstrak $(\mathrm{nmol} / \mathrm{ml})$ & 0,8438 & \pm & 0,1715 \\
B1 : Aktivitas fisik 10 menit tanpa ekstrak $(\mathrm{nmol} / \mathrm{ml})$ & 0,8571 & \pm & 0,1477 \\
B2 : Aktivitas fisik 20 menit tanpa ekstrak $(\mathrm{nmol} / \mathrm{ml})$ & 0,9455 & \pm & 0,1003 \\
B3 : Aktivitas fisik 30 menit tanpa ekstrak $(\mathrm{nmol} / \mathrm{ml})$ & 1,6161 & \pm & 0,3800 \\
Kontrol : Tidak ada aktivitas fisik, tanpa ekstrak $(\mathrm{nmol} / \mathrm{ml})$ & 0,7554 & \pm & 0,1070 \\
\hline
\end{tabular}

Keterangan : $\mathrm{MDA}=$ Malondialdehid; $\mathrm{X}=$ rata-rata; $\mathrm{S}=$ standar deviasi

Rata-rata dan standar deviasi kadar MDA plasma setelah aktivitas fisik selama 10 menit terhadap kadar malondialdehid pada mencit yang sebelumnya diberi dengan yang tidak diberi kombinasi ekstrak jeruk Brastagi dan Wortel terdapat pada tabel 1 . Selanjutnya dilakukan uji $\mathrm{t}$ independen $(p<0,05)$ untuk mengetahui perbedaan pengaruh aktivitas fisik selama 10 menit terhadap kadar malondialdehide (MDA) plasma pada mencit yang sebelumnya diberi dengan yang tidak diberi kombinasi ekstrak jeruk Brastagi dan wortel, hasilnya kadar MDA plasma mencit yang diberi kombinasi ekstrak jeruk Brastagi dan wortel lebih rendah dibandingkan dengan yang tidak diberi kombinasi ekstrak jeruk Brastagi dan wortel, seperti tercantum pada tabel 4.

Tabel 2 Hasil Pengujian Normalitas Kadar Malondialdehid Pada Mencit

\begin{tabular}{lcc}
\hline \multicolumn{1}{c}{ Perlakuan } & Z & nilai-p \\
\hline A1 : Aktifitas fisik 10 menit dengan ekstrak & 0,473 & 0,979 \\
A2 : Aktifitas fisik 20 menit dengan ekstrak & 0,612 & 0,848 \\
A3 : Aktifitas fisik 30 menit dengan ekstrak & 0,512 & 0,956 \\
B1 : Aktifitas fisik 10 menit tanpa ekstrak & 0,575 & 0,895 \\
B2 : Aktifitas fisik 20 menit tanpa ekstrak & 0,496 & 0,967 \\
B3 : Aktifitas fisik 30 menit tanpa ekstrak & 0,704 & 0,705 \\
Kontrol & 0,619 & 0,838 \\
\hline
\end{tabular}

Keterangan : $\mathrm{Z}=$ uji normalitas $(\mathrm{p}>0,05)$ data berdistribusi normal

Tabel 3 Hasil Pengujian Homogenitas Kadar Malondialdehid Pada Mencit

10 menit 20 menit $\quad 30$ menit

Perlakuan

$\begin{array}{ccc}\text { Levene's test } & \text { Nilai-p } & \begin{array}{c}\text { Levene's } \\ \text { test } F\end{array}\end{array}$

Nilai-p

Levene's
test $F$

Nilai-p

Dengan ekstrak (A)

Tanpa ekstrak (B)

$4,817 \quad 0,071 \quad 4,684$

0,074

2,032

0,204

Keterangan : $\mathrm{p}$ uji homogenitas $(\mathrm{p}>0,05)$ data homogen

Tabel 4 Uji t Independen Pengaruh Aktivitas Fisik Selama 10 Menit Terhadap Kadar Malondialdehide (MDA) Pada Mencit Yang Sebelumnya Diberi Dengan Yang Tidak Diberi Kombinasi Ekstrak Jeruk Brastagi dan Wortel

$\begin{array}{llllll}\text { Perlakuan } & \text { X } & \text { S } & \text { statistik uji t } & \text { nilai-p } & \text { Keterangan }\end{array}$

\begin{tabular}{cccccccc} 
A1 : Aktifitas fisik 10 menit \\
$\begin{array}{c}\text { dengan ekstrak } \\
\text { B1 : Aktifitas fisik 10 menit } \\
\text { tanpa ekstrak }\end{array}$ & 0,5277 & \pm & 0,0789 & $-3,936$ & $0,008^{* *}$ & $\begin{array}{c}\text { Sangat } \\
\text { signifikan }\end{array}$ \\
\hline
\end{tabular}

Keterangan : $*=$ signifikan (bermakna) pada taraf kekeliruan $5 \%(\mathrm{p} \leq 0,05)$

$* *$ = sangat signifikan (bermakna) pada taraf kekeliruan $1 \%(\mathrm{p} \leq 0,01)$ 
Rata-rata dan standar deviasi kadar MDA plasma setelah aktivitas fisik selama 20 menit terhadap kadar malondialdehid pada mencit yang sebelumnya diberi dengan yang tidak diberi kombinasi ekstrak jeruk Brastagi dan Wortel terdapat pada tabel 1 . Selanjutnya dilakukan uji $\mathrm{t}$ independen $(p<0,05)$ untuk mengetahui perbedaan pengaruh aktivitas fisik selama 20 menit terhadap kadar malondialdehide (MDA) plasma pada mencit yang sebelumnya diberi dengan yang tidak diberi kombinasi ekstrak jeruk Brastagi dan wortel, hasilnya kadar MDA plasma mencit yang diberi kombinasi ekstrak jeruk Brastagi dan wortel lebih rendah dibandingkan dengan yang tidak diberi kombinasi ekstrak jeruk Brastagi dan wortel, seperti tercantum pada tabel 5 .

Tabel 5 Uji t Independen Pengaruh Aktivitas Fisik Selama 20 Menit Terhadap Kadar Malondialdehide (MDA) Pada Mencit Yang Sebelumnya Diberi Dengan Yang Tidak Diberi Kombinasi Ekstrak Jeruk Brastagi dan Wortel

\begin{tabular}{|c|c|c|c|c|c|c|}
\hline Perlakuan & $\mathbf{X}$ & & $\mathbf{s}$ & $\begin{array}{l}\text { statistik } \\
\text { uji t }\end{array}$ & nilai-p & Keterangan \\
\hline $\begin{array}{c}\text { A2 : Aktifitas fisik } 20 \text { menit } \\
\text { dengan ekstrak }\end{array}$ & 0,5866 & \pm & 0,0589 & \multirow{2}{*}{$-6,172$} & \multirow{2}{*}{$0,001 * *$} & \multirow{2}{*}{$\begin{array}{l}\text { Sangat } \\
\text { signifikan }\end{array}$} \\
\hline $\begin{array}{c}\text { B2 : Aktifitas fisik } 20 \text { menit } \\
\text { tanpa ekstrak }\end{array}$ & 0,9455 & \pm & 0,1003 & & & \\
\hline
\end{tabular}

Keterangan : * = signifikan (bermakna) pada taraf kekeliruan $5 \%(\mathrm{p} \leq 0,05)$

$* *=$ sangat signifikan (bermakna) pada taraf kekeliruan $1 \%(\mathrm{p} \leq 0,01)$

Tabel 6 Uji t Independen Pengaruh Aktivitas Fisik Selama 30 Menit Terhadap Kadar Malondialdehide (MDA) Pada Mencit Yang Sebelumnya Diberi Dengan Yang Tidak Diberi Kombinasi Ekstrak Jeruk Brastagi dan Wortel

\begin{tabular}{ccccccc}
\hline Perlakuan & $\mathbf{x}$ & & $\mathbf{S}$ & $\begin{array}{c}\text { statistik } \\
\text { uji t }\end{array}$ & nilai-p & Keterangan \\
\hline $\begin{array}{c}\text { A3 : Aktifitas fisik 30 menit } \\
\text { dengan ekstrak }\end{array}$ & 0,8438 & \pm & 0,1715 & & & \\
$\begin{array}{c}\text { B3 : Aktifitas fisik 30 menit } \\
\text { tanpa ekstrak }\end{array}$ & 1,6161 & \pm & 0,3800 & $-3,704$ & $0,010^{*}$ & Signifikan \\
\hline
\end{tabular}

Keterangan : * = signifikan (bermakna) pada taraf kekeliruan $5 \%(\mathrm{p} \leq 0,05)$

$* *$ = sangat signifikan (bermakna) pada taraf kekeliruan $1 \%(\mathrm{p} \leq 0,01)$

Tabel 7 Uji F Analisis Varians Pengaruh Lamanya Aktivitas Fisik Terhadap Kadar Malondialdehide (MDA) Pada Mencit Yang Sebelumnya Diberi Kombinasi Ekstrak Jeruk Brastagi dan Wortel Dibandingkan Kontrol

\begin{tabular}{|c|c|c|c|c|c|c|}
\hline Perlakuan & $\mathbf{X}$ & & $\mathbf{S}$ & $\begin{array}{c}\text { statistik } \\
\text { uji F }\end{array}$ & nilai-p & Keterangan \\
\hline $\begin{array}{l}\text { A1 : Aktifitas fisik } 10 \text { menit } \\
\text { Dengan ekstrak }\end{array}$ & 0,5277 & \pm & 0,0789 & \multirow{4}{*}{6,794} & \multirow{4}{*}{$0,006 * *$} & \multirow{4}{*}{ Signifikan } \\
\hline $\begin{array}{l}\text { A2 : Aktifitas fisik } 20 \text { menit } \\
\text { Dengan ekstrak }\end{array}$ & 0,5866 & \pm & 0,0589 & & & \\
\hline $\begin{array}{l}\text { A3 : Aktifitas fisik } 30 \text { menit } \\
\text { Dengan ekstrak }\end{array}$ & 0,8438 & \pm & 0,1715 & & & \\
\hline Kontrol & 0,7554 & \pm & 0,1070 & & & \\
\hline
\end{tabular}

Keterangan : * = signifikan (bermakna) pada taraf kekeliruan $5 \%(\mathrm{p} \leq 0,05)$

$* *=$ sangat signifikan (bermakna) pada taraf kekeliruan $1 \%(\mathrm{p} \leq 0,01)$ 
Tabel 8 Uji Duncan Pengaruh Lamanya Aktivitas Fisik Terhadap Kadar Malondialdehide (MDA) Pada Mencit Yang Sebelumnya Diberi Kombinasi Ekstrak Jeruk Brastagi dan Wortel Dibandingkan Kontrol

\begin{tabular}{lcc}
\multicolumn{1}{c}{ Perlakuan } & X & Kelompok \\
\hline A1 : Aktifitas fisik 10 menit dengan ekstrak & 0,5277 & $\mathrm{~A}$ \\
A2 : Aktifitas fisik 20 menit dengan ekstrak & 0,5866 & $\mathrm{Ab}$ \\
A3 : Aktifitas fisik 30 menit dengan ekstrak & 0,8438 & $\mathrm{C}$ \\
Kontrol & 0,7554 & $\mathrm{Bc}$ \\
\hline
\end{tabular}

Keterangan : Huruf yang sama menunjukkan dalam kelompok perlakuan yang sama

Rata-rata dan standar deviasi kadar MDA plasma setelah aktivitas fisik selama 30 menit terhadap kadar malondialdehid pada mencit yang sebelumnya diberi dengan yang tidak diberi kombinasi ekstrak jeruk Brastagi dan Wortel terdapat pada tabel 1. Selanjutnya dilakukan uji t independen $(p<0,05)$ untuk mengetahui perbedaan pengaruh aktivitas fisik selama 30 menit terhadap kadar malondialdehide (MDA) plasma pada mencit yang sebelumnya diberi dengan yang tidak diberi kombinasi ekstrak jeruk Brastagi dan wortel, hasilnya kadar MDA plasma mencit yang diberi kombinasi ekstrak jeruk Brastagi dan wortel lebih rendah dibandingkan dengan yang tidak diberi kombinasi ekstrak jeruk Brastagi dan wortel, seperti tercantum pada tabel 6 .

Rata-rata dan standar deviasi hasil pengukuran kadar MDA setelah aktivitas fisik 10,20, dan 30 menit pada mencit yang sebelumnya diberi kombinasi ekstrak jeruk Brastagi dan wortel dibandingkan dengan kontrol terdapat pada tabel 1 . Selanjutnya untuk mengetahui perbedaan pengaruh aktivitas fisik 10,20, dan 30 menit terhadap kadar malondialdehid pada mencit yang sebelumnya diberi kombinasi ekstrak jeruk Brastagi dan wortel dibandingkan dengan kontrol dilakukan dengan uji $\mathrm{F}$ analisis varians. Hasil uji $\mathrm{F}$ analisis varians untuk mengetahui pengaruh aktivitas fisik selama 10, 20 dan 30 menit terhadap kadar malondialdehide (MDA) pada mencit yang sebelumnya diberi kombinasi ekstrak jeruk Brastagi dan wortel yang dibandingkan dengan kontrol, menunjukkan adanya pengaruh pemberian kombinasi ekstrak jeruk Brastagi dan wortel sebelum aktivitas fisik terhadap kadar MDA plasma dibandingkan dengan kontrol, hasilnya tercantum pada tabel 7 . Selanjutnya untuk mengetahui mana saja kelompok yang berbeda, dilakukan pengujian dengan uji Duncan yang hasilnya menunjukkan bahwa kadar MDA plasma mencit setelah aktivitas fisik selama 10 menit yang sebelumnya diberi kombinasi ekstrak jeruk Brastagi dan wortel merupakan yang terendah dibandingkan dengan kadar MDA plasma mencit setelah aktivitas fisik selama 20 dan 30 menit yang sebelumnya diberi kombinasi ekstrak jeruk Brastagi dan wortel, serta dengan kelompok kontrol. Hasil uji Duncan tersebut tercantum pada tabel 8 .

Dari hasil penelitian ditemukan bahwa pemberian kombinasi ekstrak jeruk Brastagi dan wortel sebelum melakukan aktivitas fisik selama 10,20, dan 30 menit menyebabkan penurunan kadar MDA plasma mencit dibandingkan dengan yang tidak diberi kombinasi ekstrak jeruk Brastagi dan wortel, seperti tercantum pada tabel 4, 5, dan 6 .

Aktivitas fisik yang berlangsung dalam jangka waktu yang lama maka akan menimbulkan produksi radikal bebas yang bertambah pula. Hal ini menyebakan timbunan radikal bebas akan semakin meningkat seiring bertambahnya waktu aktivitas fisik sehingga kebutuhan asupan antioksidan eksogen berupa jeruk Brastagi dan Wortel menjadi penting. Oleh karena itu pembentukan MDA di dalam darah dari waktu ke waktu akan semakin tinggi kadarnya di dalam darah, misalnya sewaktu melakukan aktivitas fisik dengan lama waktu yang berbeda akan memberikan kadar MDA yang berbeda pula. Demikian pula halnya mencit yang diberikan aktivitas fisik dengan lama waktu yang berbeda akan memberikan kadar MDA plasma mencit yang berbeda-beda pula pada berbagai interval waktu sebagaimana ditemukan pada hasil penelitian.

Terjadinya penurunan kadar MDA plasma pada pemberian kombinasi ekstrak jeruk Brastagi dan wortel oleh karena jeruk Brastagi dan wortel merupakan sumber antioksidan eksogen. Jeruk Brastagi (Citrus sinensis) adalah buah yang memiliki sifat yang khas yaitu kulit berwarna dominan hijau kekuningan dan daging buahnya mengandung banyak air. Rasanya yang manis disertai rasa asam memberikan rasa segar bagi yang memakannya. Jeruk Brastagi banyak mengandung vitamin C. 100 gram buah jeruk Brastagi mengandung $49 \mathrm{mg}$ vitamin $\mathrm{C}$ (Depkes, 2007). Jeruk Brastagi juga mengandung banyak zat lain, antara lain pektin. Pektin banyak terdapat dalam buah dan kulit jeruk, manfaatnya membantu menurunkan kadar kolesterol jahat (LDL) dan meningkatkan kolesterol baik (HDL). Jeruk juga berlimpah 
kandungan flavanoidnya yang berfungsi sebagai antioksidan penangkal radikal bebas penyebab kanker. Adapun mekanisme kerja Vitamin C sebagai antioksidan yang banyak terdapat pada jeruk Brastagi adalah sebagai berikut : Vitamin C merupakan antioksidan hidrofilik, bekerja terutama pada plasma, sitoplasma, dan mitokondria (Padayatty, 2003; June, 2000). Vitamin C memainkan peranan penting sebagai pertahanan ekstra membran sel melawan serangan radikal bebas oksigen. Menurut Shiel (2006) vitamin C bekerja sebagai donor elektron atau senyawa reduksi. Vitamin C akan mendonorkan dua elektron dari ikatan ganda antara rantai karbon 2 dan 3 kepada radikal bebas. Saat kehilangan satu elektron maka vitamin $\mathrm{C}$ akan teroksidasi menjadi radikal bebas askorbic radicals yang relatif lebih stabil dan tidak reaktif dibandingkan radikal bebas lain. Bila vitamin C kehilangan satu elektron lagi, maka vitamin C akan teroksidasi menjadi bentuk yang jauh lebih stabil dibanding bentuk ascorbic radicals yaitu berbentuk dehydroascorbic acid.

Demikian pula halnya wortel yang mengandung $\beta$ karoten. Sebagai antioksidan yang bersifat hidrofobik. $\beta$ karoten dapat bekerja langsung terhadap peroksidasi membran sel. Karoten memiliki kemampuan untuk memecah singlet oksigen, yang lebih reaktif pada keadaan aerob dibandingkan dengan triplet oksigen. Karoten dapat berinteraksi dengan radikal bebas lain dan memecahnya menjadi produk nonradikal (Shils, 2006). Karoten bereaksi dengan singlet oksigen dengan cara pemecahan fisik dimana terjadi perpindahan energi dari singlet oksigen ke karotenoid dan diikuti dengan perpindahan panas dan reaksi kimia yang berakhir saat karotenoid dihancurkan dalam proses penambahan oksigen pada ikatan gandanya. Reaksi karoten dengan radikal lipid menghasilkan molekul berinti karbon yang radikal. Pada proses selanjutnya molekul ini dapat menjadi prooksidan bila berada pada suasana aerob. Namun juga dapat bereaksi dengan lipid dan membentuk senyawa yang stabil. Sehingga pada tekanan oksigen yang rendah maka karoten berfungsi sebagai antioksidan (Papas, 1999). Pada penelitian yang dilakukan Lieber, dilaporkan bahwa karoten merupakan antioksidan yang efektif untuk melawan 2,2'-azobis (2 aminodipropane) dihydrochloride (AAPH) yang menginduksi peroksidasi lipid (Cutler, 2003).

\section{KESIMPULAN}

Uraian di atas menyimpulkan bahwa pemberian kombinasi ekstrak jeruk Brastagi dan wortel sebelum aktivitas fisik menunjukkan proses penurunan kadar MDA.

\section{DAFTAR PUSTAKA}

1. Ames, B., Shigenaga, M. K., Hagen, T. 1993. Oxidants, Antioxidants, and Degenerative Diseases of Aging. Proc Nationl Acad Sci 90:7915-22.

2. Astrand, P.O., Rodahl, K. 1986. Textbook of Work Physiology, Physiological Bases of Exercises $3^{\text {th }} \mathrm{Ed}$. New York. Mc Graw. Hill Book Company. p: $293-$ 348, 501-512, 523-576, 684.

3. Atalay, N. 2007. Effect of Different Resistance Exercise Protocols on Nitric Oxide, Lipid Peroxidation, and Creatine Kinase Activity in Sedentary Males. Ankara.

4. Azwar, A., Prihartono, J., 1987. Metodologi Penelitian Kedokteran dan Kesehatan Masyarakat. Ed 1. Jakarta: P.T. Binarupa. p: 25-60.

5. Berner, Y. N. 2006. Nutrition and aging. Turkish J of Geriatrics. 2:097-107.

6. Block, G.,Norkus, E., Hudes, M., Mandel, S., Helzlsouer, K. 2001. Which Plasma Antioxidants Are Most Related to Fruit and Vegetable Consumption?. American J of Epid. 154(12) : 1113-1118.

7. Booron, WF., Boulpep, EL. 2003. Medical Physiology. Philadelphia; Elsevier Saunders.

8. Brooks, A. And Fahey, D. 1985. Exercise Physiology. Human Bioenergetics and Applications.

New York. Mc Millan Publishing Company. p; 701722

9. Campbell, N.A.,etc. 2000. Third ed., Biology; Concept and Connections. New York. Benjamin Cummings, An imprint of Addison Wesley Longman, Inc.

10. Carr, A.C., Frei, B. 1999. Toward A New Recommended Dietary Allowance for Vitamin C based on Antioxidant and Health Effects in Humans. American J of Clin Nutr. 69;1086-107.

11. Carre, F.A., Corbin, C. B., Lindsey, R. 1980. Physical Education Concepts : Fitness for Life. Canada: Gage Publising Limited.

12. Chappell, M., et al. 2004. Voluntary running in deer mice: speed, distance, energy costs and temperature effects. J of Experiment Biol. 207: 3839-3854.

13. Chen, Q., espey, M.G., Sun, A.Y., et al. 2007. Ascorbate in Pharmacologic Concentrations Selectively Generates Ascorbate Radical and Hydrogen Peroxide in Extracellular Fluid in vivo. National Institutes of Health, Bethesda MD.

14. Clarkson, P. M., Thompson, H. S. 2000. Antioxidant: What Role do They Play in Physical Activity and Health. The American J of Clin Nutr, 72(2):637S646S. 
15. Collins, A. 2005. Assays for Oxidative Stress and Antioxidant Status: Applications to Research into The Biological Effectiveness of Polyphenols. American J of Clin Nutr. 81(1): 261S-267S.

16. Congy, F., Bonnefont-Rousselot, D., Dever S., et al. 1995. Study of Oxidative Stress in The Elderly. Europe PMC. 24:1115-1118.

17. Cross, CE., Valacchi, G., Schock, B., Wilson, M., Weber, S., Eiserich, J and Van der Vliet A. 2002. Environmental Oxidant Pollutant Effects on Biologic Systems, A Focus on Micronutrient AntioxidantOxidant Interactions. American $J$ of Resp and Critical Care Med. 166:S44-S50.

18. Ctler, R.G., Rodriguez, H., 2003. Critical Reviews of Oxidative Stress and Aging, Advances in Basic Science, Diagnostics and Intervention. New Jersey: World Scientific.

19. Ditjen, BP Hortikultura, Direktorat Tanaman Buah, Vademekum Jeruk. 2002. Daftar Kandungan Gizi dalam 100 gram Jeruk. Jakarta: Ditjen BP Holtikultura.

20. Droge, W. 2002. Free Radicals in the Physiological Control of Cell Function. American Physiol Soc Physiol Rev. 82: 47-95

21. Evans, W.J. 2000. Vitamin E, vitamin C, and Exercise. American J of Clin Nutr. 72(2), 647S-652S.

22. Finkel, T. 2003. Oxidant Signals and Oxidative Stress I (review). Curr Opin Cell Biol. 15; 247-254.

23. Finkel, T. Hoolbrook, NJ. 2004. Oxidants, Oxidative Stress and The Biology of Aging (review). Nature; 408; 239-47

24. Foss, M. L., Keteyian, S.J. 1998. Foxs Physiological Basic for Excercise and Sport $6^{\text {th }}$ Ed. United States: Mcgraw Hill company.

25. Fox, L. 1979, Sports Physiology. Philadelphia: W.B. Saunders Company. p: 27-34.

26. Fox, L.E, Bower, W.R; Foss, M.L, 1988. The Physiological Basic of Physical Education. Philadelphia: Fourth Edition, Saunders College Publishing. p:166.

27. Frei, B.. 2003. To C or Not to C, That is the Question!. J of American Col of Cardiol. 42(2); 246255.

28. Fukutomi, Takayama., Akashi, Tanaka, S. Nanasawa, T., Matsuo, K. Et al. 2001. Multicentricity and histopathological Features of Familial Breas Cancers Stratified by Menopausal Status. Int. J. Clin Oncol. 6; 80-83.

29. Ganong, W. 1983., Review of Medical Physiology, $11^{\text {th }} E d$. California: Lange Medical Publications. Los Altos. p:25; 52-53; 225-232; 580-582; 591-596.

30. Giam, C.K., Teh, K.C. 1993. Sport Medicine: Exercise and Fitnes. Singapore.PG Publising Pte Ltd.
31. Guyton, A. 2000. Text Book of Medical Phyisology, $10^{\text {th }} \mathrm{Ed}$. Philadelphia: W.B.Sounders Company/Igaku Shoin. p; 133, 438-451, 808-817, 1010-1014.

32. Haliwell, B. 2001. Role of Free Radicals in Neurodegenerative Disease, Therapeutic Implications for Antioxidant treatment (Review). Drugs Aging. $18 ; 685-716$

33. Haliwell, B., Gutteridge., 1998. Free Radical in Biology and Medicine $2^{\text {nd }} E d$. New York : Oxford University Press.

34. Haliwell, B., Whiteman M. 2004. Measuring reactive species and oxidative damage in vivo and in cell culture; how should you do it and the results mean (Review). British J Pharmacol. 142; 31-55.

35. Halvorsen, B.L., et al. 2006. Content of redox-active compounds (ie, antioxidants) in foods consumed in the United States. American J of Clin Nutr. 84(1):95135

36. Handelman, G.J, Pryor, W.A. 1999. Evaluation of Antioxidant Status in Humans. Dalam Papas, AM (penyunting), "Antioxidant Status, Diet, Nutrition, and Health", London : CRC Press. p:47.

37. Harsono. 1988, Coaching dan Aspek-Aspek Psikologis dalam Coaching, Jakarta: CV. Tambak Kusuma. p: 100, 172, 174.

38. Hathcock, J., Azzi, A., Blumberg, J., Bray, T., Dickinson, A., Frei, B., et al. 2005. Vitamins E and C are safe across a broad range of intakes. American $J$ of Clin Nutr, 81(4):736-745.

39. Heber, D. 2004. Phytochemical Effects beyond Antioxidation. J Nutr. 134:3143S-3163S.

40. Hu, Y, Block, G., Norkus, E.P., Morrow, J.D., Dietrich, M., Hudes, M.. 2006. Relations of glycemic index and glycemic load with plasma oxidatives stress markers. American J of Clin Nutr. 84(1):70-76.

41. Ji, L. 1999. Antioxidants and oxidative stress in exercise. Madison: Department of Kinesiology, Interdepartmental Program of Nutritional Sciences, and Institute on Aging, University of Wisconsin.

42. Ji, L., Leuwenburgh, C., Leichtweis, S., et al. 1998. Oxidative Stress and Aging: Role of Exercise and Its Influences on Antioxidant Systems. Annals of the New York Acad of Sci. 854:102-117.

43. June, H., Mc.Dermott. 2000. Antioxidant Nutrients: Current Dietary Recommendations and Research Update. $J$ of the American Pharmaceutic Assoc. 40(6):785-799.

44. Kantr, M., Nolte, L.A., Holloszy.1993. Effect of an antioxidant vitamin mixture on lipid peroxidation at rest and post exercise. $J$ of Appl Physiol, 74 (2):965969.

45. Keren, Clippinger, Robertson, 1986. Aerobics Instructor Manual The Resource for Fitness 
Professional. Sandiago California: Publisher, American Council or Exercise. p:209-210.

46. Klaining, J.E., Kamendulis, L.M. 2004. The Oxidative Stress in carcinogenesis (Review). Annu Rev Pharmacol Toxicol. 44; 239-67.

47. Lasheras, C., Huerta, J. M., Gonzalez, S.; et al. 2002. Independent and Interactive Association of Blood Antioxidants and Oxidative Damage in Elderly People. Free Radical Research, 36(8):875 - 882.

48. Leeuwenberg, C. , Heinecke, JW. 2001. Oxidative Stress and Antioxidant in Exercise. Curr Medicin Chemistr. 8:829-838.

49. Leeuwenberg, C. , Phaneuf, S. 2001. Apoptosis and Exercise. Med Sci Sports Exerc, 33:393-396.

50. Levine, M., Wang, Y., Padayyaty, S.J. et al. 2001. A New Recommended Dietary Allowance of Vitamin $C$ for Healthy Young Women. United States: National Institutes of Health, Bethesda, MD.

51. Madiyono, B., Moeslichan, S., Sastroasmoro, S., Budiman, I., Purwanto, S.H. 2002. Perkiraan Besar Sampel. Dalam Sastroasmoro S dan Ismael S (penyunting) "Dasar-Dasar Metodologi Penelitian Klinis, Ed. 2", hlm. 269. Jakarta : CV Sagung Seto.

52. Masud, I., 1989. Dasar-dasar Fisiologi Kardiovaskular. Jakarta:EGC

53. Mathew, D., Fox, L. and Van Hold, K. 1990. Biochemistry. New York: The Benjamin Cummings Publishing Co. Inc. p: 381-403, 433-569.

54. Mayes, A.P., Murray, K.R., Granner, D.K., et all. 2000, Harper's Biochemistry $25^{\text {th }} \mathrm{Ed}$, Philadelphia: W.B. Sounders Company/Igaku Shoin. p:115-130.

55. Mayne, S.T. 2003. Antioxidant Nutrients and Chronic Disease: Use of Biomarkers of Exposure and Oxidative Stress Status in Epidemiologic Research. $J$ Nutr. 133:933S-940S.

56. Mc.Williams, M. 1985. Food Fundamental $4^{\text {th }}$ ed. New York : Macmillan Publishing Company.

57. Nielsen, F., Mikkelsen, B., Nielsen, J., et all. 1997. Plasma Malondialdehyde as Biomarker for Oxidative Stress: Reference Interval and Effects of Life-Style Factors. American Assoc for Clin Chemist, 7:12091214.

58. Ningtias, P.A. 2007. Pengaruh Pemberian $\beta$ Carotene dalam Wortel Kukus (Daucus carota L.) terhadap Kadar Malondialdehid Plasma pada Subjek yang Terpapar Polusi Gas buang Kendaraan Bermotor di Alun-alun Kota Bandung. Tesis. Program Pascasarjana Combined Degree Fakultas Kedokteran Universitas Padjadjaran. Bandung.

59. Noguchi, N., Niki, E. 1999. Chemistry of Active Oxygen Species and Antioxidants. Dalam Papas, A.M. (penyunting), "Antioxidant Status, Diet, Nutrition, and Health", hlm10. London : CRC Press.
60. Padayatty, Sebastian, J, Levine, M. 2001. New Insight Into The Physiology and Pharmacology of Vitamin C. CMAJ. 2001; 164:163.

61. Padayatty, Sebastian, J, Levine, M. 2008. Fruits and Vegetables: think Variety, Go Ahead, Eat. Am J Clin Nutr. 87; 5-7.

62. Padayatty, Sebastian, J. 2003. Vitamin C as an Antioxidant: Evaluation of Its Role in Disease Prevention. $J$ of the American Col of Nutr, 22(1):1835.

63. Papas, A.M. 1999. Antioxidant Satus, Diet, Nutrition, and Health. USA : CRC Press.

64. Percival. 2001. Oxidatice Stress and Antioxidants in Exercise.Current Medicinal Chemistry. USA Bentham Science Publisher.

65. Pryor, R.L. 2003. Fruits and vegetables in the prevention of cellular oxidative damage. American $J$ of Clin Nutr, 78(3): 570S-578S.

66. Reilly, T., Secher, N., Snell, P., Williams, C. 1990. Phsyiology of Sport. London: Chapman \& Hall.

67. Riso, P., Pinder, A., Santangelo, A., et al.1999. Does Tomato Consumption Effectively Increase The Resistance of Lymphocyte DNA to Oxidative Damage?. American J of Clin Nutr, 69(4):712-718.

68. Rock, C.L., Lovalvo, J., Emenhiser, C., et.al. 1998. Bioavailability of $\beta$-Carotene Is Lower in Raw than in Processed Carrots and Spinach in Women. The J of Nutr. 128(5):913-916.

69. Roecker, K., Niess, A.M., Horstmann, T., Striegel, H., Mayer., Dickguth, H.H., Medical \& Science in Sports \& Exercise. Volume 34 number 5. May 2002. USA: Lippincott Williams \& Wilkins. p:881.

70. Rushall, B. Pyke, F.S. 1990. Training for Sport and Fitness, Australia: The Mc. Millan Company of Australia Ltd, p:263.

71. Schumacher, Y.O., Schmid, A., Grathwohl, D., Bultermann, D., Berg, A. 2002. Med \& Sci in Sports \& Exercise. New York: Lippincott Williams \& Wilkins. p:869.

72. Sentra Informasi IPTEK. 2000. Tanaman Obat Indonesia; Wortel. Jakarta: IPTEK Indonesia.

73. Sherwood, Lauralee. 2006. Human Physiology; From Cell to System, $4^{\text {th }}$ Ed. USA: Belmont CA; Wrisworth Publishing Company.

74. Shi J., Le Maquer. 2000. Lycopene in Tomatoes: Chemical and Physical Properties Affected by Food Processing. Critic Reviews in Food Sci and Nutr. 40(1): 1-42

75. Shils, M.E., Ross, C.A. 2006. Modern Nutrition in Health and Disease, $10^{\text {th }} \mathrm{Ed}$. Baltimore: Lippincott Williams and Wilkins.

76. Stahl, W., Sies, H. 1992. Uptake of lycopene and its geometrical isomers is greater from heat-processed 
than from unprocessed tomato juice in human. $J$ of Nutr. 122:2161-2166.

77. Stang, J., Story, M. 2005. Nutrition screening, assessment, intervention. $J$ of Parenteral and Enteral Nutr. 35(1):16-24.

78. Stocker, R., Keaney, JF., Jr. 2004. Role of Oxidative Modifications in Atherosclerosis (Review). Physiol Rev. 84; 1381-1478.

79. Sudjana. 1992. Metode Statistika, Ed 5. Bandung: Penerbit, Tarsito. hlm: 261- 466.

80. Trevisan, M., Browne, R., Ram, M., Muti, P., Freudenheim, J., Carosella, $\mathrm{M}$ and Amstrong, D. 2001. Correlates of Markers of Oxidative Status in the General Population. American $J$ of Epid, 154(4):348-356,

81. Van Het Hof, K. H., West, C. E., Weststrate, J. A., Hautvast, G. 2000. Dietary Factors That Affect the Bioavailability of Carotenoids. J of Nutr. 130:503506.

82. Winarsi, H., M.S., 2007. Antioxidan Alami dan Radikal Bebas. Yogyakarta: Penerbit Kanisius.

83. Wirya, I. W. 2006. Pemberian asam askorbat pada pelari sprint $200 \mathrm{~m}$ untuk meredam pembentukan radikal bebas yang diukur dari penurunan malondialdehid dan laktat plasma. Tesis. Universitas Lampung. 